\title{
NICOLAU MAQUIAVEL: A AÇÃO TUMULTUÁRIA NA ORIGEM DA LIBERDADE
}

\author{
Nicolo Machiavelli: The tumultuous action \\ at the origin of liberty
}

\section{Márcia Gomes Fernandes*}

\begin{abstract}
Resumo: O objetivo do presente artigo é demonstrar que Nicolau Maquiavel, em sua obra Comentários sobre a Primeira Década de Tito Livio "Discorsi", promoveu um rompimento com a intelectualidade do medievo ao defender que os "tumultos" são um mal necessário para a conquista da liberdade. Segundo Maquiavel, o instrumento necessário para que isso ocorra é a existência de boas leis, que regulem os conflitos sociais para que esses não se desviem dos interesses coletivos.

Palavras-chave: Nicolau Maquiavel; Pensamento Político Medieval; Humores.
\end{abstract}

\begin{abstract}
The purpose of this article is to demonstrate that Nicolo Machiavelli, in his work Comments on the First Decade of Titus Livio "Discorsi", promoted a rupture with the intellectuality of the Middle Ages when he defended that of disorder as a necessary evil for the liberty, According to Machiavelli, the required instrument for this is the existence of good laws, which regulate social conflicts so that they do not deviate from the collective interests.
\end{abstract}

Keywords: Nicolo Machiavelli; Political Medieval Thought; Humours.

\section{Introdução}

Nicolau Maquiavel (1469-1527) ascendeu ao cenário político florentino em 1498, quando foi designado Secretário da Segunda Chancelaria, cuja função era representar o Estado nas missões externas na tentativa de defender Florença das ambições imperialistas do Papado e do Império ${ }^{1}$. Maquiavel ocupou a Segunda Chancelaria por quatorze anos e durante esse período de exercício da diplomacia tornou-se um habilidoso analista do cenário político europeu, tecendo análises sobre política - sendo reconhecido como um grande analista e teórico da política na Itália. No entanto, à medida que se intensificavam as ameaças externas, aumentava a vulnerabilidade dos Estados

\footnotetext{
* Doutora em História Social pela Universidade de São Paulo (USP). Professora do Colegiado de História da Universidade Federal do Amapá (UNIFAP), Brasil. E-mail: marcia.gomesfernandes@gmail.com

1 O Norte da Itália, já na metade do século XII, perdera seu caráter feudal e instituiu novas formas de organização política e social. Como resultado, as cidades italianas estimuladas pelo desejo de liberdade tornaram-se repúblicas independentes, nas quais o poder era exercido pelos cônsules eleitos anualmente. No entanto, a liberdade das cidades italianas era constantemente ameaçada pelas investidas dos Imperadores do Sacro Império Romano-Germânico e também dos Pontífices. As intervenções militares do Império tinham como base legal o Código Justiniano, o qual enunciava que o princeps era o dominus mundi. Partindo desse princípio, os juristas associavam a figura do princeps a do Imperador. Quanto aos Papas, fundamentavam suas investidas a fim de governar in temporalibus no Código de Direito Canônico e na elaboração de Bulas para ampliar a legitimidade da plenitudo potestatis. Para garantir a legitimidade da libertas, juristas e intelectuais deram início a uma empreitada ideológica visando à reinterpretação das leis e a anulação da legitimidade do poder sobre a Itália, por parte dos Imperadores e dos Pontífices.
} 
italianos. Após uma série de ameaças e negociações no início de 1512, a República Florentina enfrentou uma grande reviravolta política, o primeiro gonfaloneiro ${ }^{2}$ Piero Soderini abandonou o governo, por pressão da Espanha, e partiu para o exílio em Siena. Em setembro do mesmo ano, a família Médicis ${ }^{3}$, apoiada pelo Papa Júlio II, retornaram do exílio e assumiram novamente o poder em Florença. Toda a estrutura governamental que sustentava a Signoria e o próprio cargo de Nicolau Maquiavel foi desmantelada. O novo governo passou a ser liderado por um Parlamento composto por cidadãos ricos e aliados aos Médicis - o Cardeal Giovanni de Médici e Giuliano de Médici. Em novembro de 1512 Nicolau Maquiavel foi dispensado de todas as suas funções no Estado florentino.

Nicolau Maquiavel foi um homem preocupado e obstinado em salvar uma Itália dividida e subjugada pelas ameaças externas. Ciente de sua importância na política florentina, Maquiavel buscou compreender e propor soluções para o cenário político que emergia dos Estados italianos, especificamente em sua terra natal - Florença. O pensador florentino debruçou-se sobre a Antiguidade para apreender sua história e construir um paradigma que possibilitasse a compreensão de seu presente. Este estudo resultou na tomada da República Romana como um modelo de perfeição. Segundo Maquiavel, a perfeição da República Romana estaria no fato dessa ter sido capaz de alcançar sua grandeza ao criar espaços institucionais para a canalização dos conflitos sociais ou a ocorrência dos humores, como denominava Nicolau Maquiavel ${ }^{4}$. Ao tomar a República Romana como um modelo, o pensador florentino defende que os conflitos sociais são benéficos, pois os tumultos em Roma visavam ao bem coletivo e eram deles que emergiam as leis que garantiam a conquista e a manutenção da liberdade. No entanto, a ação tumultuária somente levaria à conquista da liberdade numa sociedade que não estivesse corrompida e onde os indivíduos tivessem boas intenções para com a coletividade. Caso contrário, como foi o exemplo de Florença à época de Maquiavel, os tumultos gerariam faccionismo, desordem, desigualdades e a perda da liberdade.

[...] dos Tarquínios aos Gracos, durante mais de trezentos anos, os tumultos de Roma raras vezes redundaram em exílio e raríssimas vezes em sangue. Portanto, não se pode dizer que tais tumultos sejam nocivos, nem que tal república fosse dividida, se em tanto tempo, em razão de suas diferenças, não mandou para o exílio mais que oito ou dez cidadãos, matou pouquíssimos e não condenou muitos ao pagamento de multas. E não se pode ter razão para chamar de não ordenada uma república dessas, onde há tantos exemplos de virtù; porque os bons exemplos nascem da boa educação; a boa educação, das boas leis; e as boas leis, dos tumultos que muitos condenam sem ponderar: porque quem examinar bem o resultado deles não descobrirá que eles deram origem a exílios ou violências em desfavor do bem comum, mas sim a leis e ordenações benéficas à liberdade pública. (Maquiavel, 2000:22). ${ }^{5}$

\footnotetext{
2 Magistrado municipal das repúblicas italianas na Idade Média.

3 Os Médicis foram uma família rica e poderosa de comerciantes e banqueiros que exerceram domínio sobre Florença durante os séculos XV e XVI. Além de exercerem o poder político em Florença, os Médicis também conquistaram o Papado com a eleição de Giovanni de Médici, em 1513, como Papa com o nome de Leão $\mathrm{X}$.

${ }^{4}$ Ao aplicar o conceito dos humores (que desde a Antiguidade estava vinculado à fisiologia humana) ao corpo social e político, Nicolau Maquiavel converte-o num conceito de cunho político caracterizado por um desejo de dominar - no caso dos grandes - e pelo desejo de não ser dominado - no caso do povo.

${ }^{5}$ Dois importantes conceitos no pensamento de Nicolau Maquiavel é a fortuna e a virtù. 0 pensador florentino chama de fortuna a presença permanente de uma força na vida pública que altera o rumo dos acontecimentos em momentos decisivos. Nesse sentido, pensar a política é considerar o fato de que alguns acontecimentos não podem ser previstos. Em relação à virtù, Maquiavel a compreende como a capacidade que alguns homens têm de agir de forma eficaz em determinadas circunstâncias.
} 
Propomos que a Teoria dos Humores ${ }^{6}$ de Nicolau Maquiavel - tratada especialmente na obra Comentários sobre a Primeira Década de Tito Livio "Discorsi"' - marcou o momento de ruptura com a tradição do pensamento político medieval que atribuía às dissensões sociais a causa da perda da pax et concordia. Os pensadores que antecederam Nicolau Maquiavel refletiram sobre a questão dos conflitos civis e contribuíram para o enriquecimento do debate intelectual propondo análises sobre a liberdade, a prática da virtù, a defesa de um governo independente e a manutenção da paz. Nicolau Maquiavel dialogou com a intelectualidade do medievo dando continuidade às análises dessas temáticas. Porém, promoveu um rompimento com a tradição do pensamento medieval ao defender as discórdias civis como um mal necessário, ao afirmar que o fim último das dissensões sociais é a garantia da liberdade.

Um importante pensador que se debruçou sobre as questões políticas de sua época foi o florentino Dante Alighieri (1265-1321).Em sua obra De La Monarquia(redigida entre os anos de 1309-1313), Dante retorna ao conceito de Império Universal ${ }^{8}$, apontando como justificativa a necessidade do bem-estar mundial, que diante do cenário de guerras e intranquilidade o Imperador seria, para o pensador florentino, o ponto de equilíbrio. Dante propôs como conceito de Império não o poder concentrado nas mãos de um único governante e num determinado Estado; mas sim, o exercício da política por todos os homens. Esta ideia de Império é central no pensamento de Dante Alighieri. Em sua obra De La Monarquia, Dante apresenta uma doutrina de governo marcada pelo caráter universalista.

Hay que buscar, pues, elfin universal da la sociedaddel género humano, porque si cada sociedad tiene su fin, el conjunto de todas las sociedades há de tener también su fin único y común. El findel género humano en total es distinto de los fines de los elementos y sociedades menores que lo forman, puesto que la sociedad del género humano existe, y en el universo no hay nada ocioso, nada que no tenga su rázón de ser. Ha de haber, pues, una operación propia de toda la humanidad, que no pueda ser realizada ni por el hombre aisla doni por una agrupación parcial, sino solamente por la humanidad misma em su conjunto (Alighieri,1941:12).

Dante Alighieri opera uma sistematização na qual o gênero humano deve agir, por meio de seu intelecto, a fim de alcançar um fim único na vida presente. Fim que só é possível atingir com a união de todo o gênero humano. Ou seja, sacrificar cada um dos agrupamentos em benefício de um fim maior e universal. Este fim é a liberdade pela qual podemos desfrutar da paz universal. E esse fim só seria alcançado numa Monarquia, que promoveria o bem estar no mundo.

Na obra De La Monarquia, Dante não defende a existência de um grupo homogêneo de pessoas submetidas a um Monarca. Cada grupo - família, aldeias, cidades e reinos - devem preservar sua autonomia, seus costumes e suas leis. No entanto, Dante propõe que para atingir determinados fins é preciso a submissão ao Monarca; e este fim é a felicidade obtida por meio da manutenção da paz. Conquanto, sendo o fim desejável a paz universal entre o gênero humano, Dante

\footnotetext{
${ }^{6}$ Denominamos Teoria dos Humores a tese na qual Nicolau Maquiavel defende que os conflitos internos são saudáveis e foram responsáveis pela grandeza de Roma. Porém, Maquiavel salienta que para os conflitos serem positivos é preciso que sejam travados dentro de um quadro institucional reconhecido por todos como legítimo.

${ }^{7}$ A Teoria dos Humores também foi abordada por Nicolau Maquiavel nas obras História de Florença e 0 Príncipe.

80 conceito de Império Universal tem origem com Carlos Magno, que visava a reconstruir o antigo Império Romano.
} 
aponta os conflitos de interesses, que caracterizam as relações sociais, como causa da destruição da paz. Dessa forma, a sujeição a um governo único e universal promoveria o fim das facções e desordens. Dante Alighieri compreende que o Imperador seria a única força unificadora capaz de eliminar as desordens e garantir a manutenção da paz.

Evidentemente que a teoria de uma Monarquia Universal não se aplicaria de fato. Mas é compreensível a preocupação de Dante ao compor sua obra, ele está refletindo sobre questões que sua época lhe apresenta. O Regnum Italicum estava sob o julgo papal', enquanto que Henrique VII (1457-1509) marchava sobre a Itália. Disso decorreu a doutrina de uma Monarquia Universal seria Henrique VII a esperança para salvar a Itália.

Outro importante pensador que antecedeu Nicolau Maquiavel e refletiu sobre as dissensões civis foi Marsílio de Pádua (1275-1342), cuja principal obra produzida foi O Defensor da Paz (publicada em 1324). Marsílio de Pádua foi acusado de herético e excomungado pelo Papa João XXII em virtude das teses defendidas em O Defensor da Pa\%, por isso refugiou-se na Corte do Imperador Luís da Baviera, a quem serviu como conselheiro político até sua morte ${ }^{10}$.

Há no pensamento de Marsílio de Pádua uma temática central: a busca pela paz. Dentre uma série de eventos que contribuíram para o não estabelecimento da paz, o que Marsílio de Pádua aponta como a principal ameaça à paz é a "causa particular da discórdia", cuja natureza seria a opinião errônea que alguns bispos de Roma possuíam a respeito da plenitudo potestatis conferida por Cristo aos seus apóstolos e no perverso desejo de governar que os mesmos atribuíam a si próprios. Marsílio de Pádua compreendia a paz enquanto paz civil, entendida como uma organização racional das partes da cidade, de modo que cada uma delas realizasse bem sua função, conforme sua razão e instituição, garantindo a finalidade de uma cidade que é proporcionar aos seus cidadãos o viver bem. O filósofo paduano adota o conceito aristotélico de cidadão: "[...] considero cidadão aquela pessoa que, na comunidade civil, participa do governo ou da função deliberativa ou da judicativa, conforme seu posto."(Pádua, 1997:131).

Partindo do princípio aristotélico, Marsílio de Pádua concebe a paz com base em concepções puramente naturais: a paz corresponde à ausência de conflitos, a um estado terreno perfeito; sendo o instrumento para o alcance da paz no interior da sociedade civil a cidade - civitas. A paz não é obra da caridade, mas sim o resultado de interesses recíprocos de natureza biológica e econômica. Neste sentido, Marsílio de Pádua destitui a ordem moral como pressuposto para a busca pela paz. No entanto, devemos atentar para o fato de que o filósofo paduano concebe a paz tendo em vista somente a paz civil, a qual é fruto das relações harmoniosas entre os indivíduos na civitas $^{11}$.

Com relação à civitas, Marsílio de Pádua rompe com a tradição agostiniana ${ }^{12}$ ao caracterizá-

\footnotetext{
9 Dante Alighieri não aprovava o exercício do poder temporal pelo Papado.

10 Predominava uma querela entre os sucessivos pontífices João XXII (1316-1334), Bento XII (1334-1342) e Clemente VI (1342-1352) e o Imperador Luís da Baviera (1314-1347). Essa querela iniciou-se quando o Papa João XXII atribuiu-se o direito de nomear, controlar e julgar o Imperador. O conflito foi desencadeado quando da morte do Imperador Henrique VII (1313), o Papa João XII nomeou o rei de Nápoles, Roberto I, ao trono imperial. Em 1322, Luís da Baviera destrona Roberto I e assume o Império. Diante dessa atitude, João XXII excomunga Luís, acusando-o de heresia e de usurpador de direitos alheios. Quando em julho de 1324, o Papa João XXII declara Luís da Baviera deposto. É nesse contexto que Marsílio de Pádua redigiu sua obra O Defensor da Paz, visando provar que o poder imperial não provinha do Papa, como também, que o Imperador não deveria submeter-se aos Pontífices.

11 Marsílio de Pádua formula uma relação de circularidade entre a lex e a civil em pacem, onde essa é ao mesmo tempo origem e consequência da lex.

12 Em Santo Agostinho, o conceito de civitas relaciona-se à distinção entre duas cidades: a de Deus e a dos homens. Essa distinção tem apenas um caráter místico. Em seu pensamento, há uma única e só república
} 
la como uma sociedade inteiramente natural, que existe somente para a realização de seus próprios fins. Além disso, é na cidade que existem os instrumentos para a conquista da paz, sendo o principal deles a boa organização das partes que a compõem e a realização de suas funções. Portanto, como as partes integrantes de um ser vivo devem estar em função de sua saúde, da mesma forma as partes integrantes da cidade devem estar organizadas com o propósito de propiciar a tranquilidade aos seus habitantes ${ }^{13}$. Para Marsílio de Pádua

[...] a tranquilidade reside na boa organização da cidade, de acordo com a qual cada uma de suas partes desempenhe totalmente as tarefas que lhe são peculiares, conforme a razão e o motivo graças aos quais foram instituídos. (Pádua, 1997:77).

Marsílio de Pádua atribui à civitas uma dimensão exclusivamente terrestre. A civitas é um todo perfeitamente natural: sua causa é a tendência natural dos homens à sociabilidade, a origem da cidade está na vontade racional e seu objetivo é a felicidade e o bem-estar da comunidade. No entanto, para que haja a paz civil é necessária a existência de uma lei ou norma que regule todos os indivíduos. Do contrário, os conflitos sociais promoveriam a destruição da civitas.

Todavia, entre os homens assim reunidos ocorreram rixas e contendas que, se por acaso não estivessem regulados por uma norma de justiça, teriam sido a causa de guerras e da separação dos seres humanos e finalmente ocorreria então a própria destruição da cidade. (Pádua, 1997:85).

Para o filósofo paduano o fim último da civitas é a manutenção da paz civil e do bem comum. No entanto, esses dois elementos dependem do viver e do viver bem entre o populus ${ }^{14}$, e o viver bem, para o filósofo, pressupõe a existência da lex, a qual regularia os atos humanos e garantiria que cada parte da civitas cumprisse a sua função. Para Marsílio de Pádua não há lugar para os desejos e paixões pessoais, uma vez que esses sentimentos colocariam em risco a civitas. Por isso a necessidade das leis, Marsílio de Pádua atribui às leis um valor imensurável, pois somente a legislação impedirá a ocorrência de discórdias civis, às quais culminariam na destruição da civitas.

Por fim, temos o florentino Coluccio Salutati (1331-1406), que refletiu sobre temas como as discórdias civis e a liberdade. Foi Chanceler entre os anos de 1375 a 1406, tendo relevante participação nos movimentos políticos da República Florentina. Em sua obra Invettiva contro Antonio Loschi da Viceņ̃a (1403), Salutati reflete sobre a virtù, insistindo na importância de sua redefinição, uma vez que as transformações na sociedade medieval passavam a exigir uma nova teoria quanto à ação humana na pólis. No entanto, há no pensamento de Salutati um tema central que é a paz. O pensador florentino atribui um grande peso à preservação da paz e por isso defende a instalação de um governo monárquico quando da ocorrência de discórdias internas e guerras. Percebemos no

de todos os cristãos: “omnium enim christianorum uma respublica est”. Por reivindicarem uma mesma fé, todos os cristãos formam uma única sociedade espiritual.

13 Marsílio de Pádua distingue seis partes constituintes da cidade, onde cada uma exerce sua função de maneira harmoniosa. São elas: a agricultura (incluindo a pecuária, caça e pesca) - necessária à produção de alimentos; o artesanato - fabrico de utensílios e desenvolvimento tecnológico; o judicial - responsável em regular a justiça com vistas ao bem comum; o exército - encarregado pela defesa da cidade; os financistas - responsável pela riqueza e pelo comércio; e por fim o sacerdócio - grupo que prepara e julga os homens para a vida espiritual.

14 Na obra de Marsílio de Pádua, a palavra populus significa o conjunto dos cidadãos da civitas. Sendo cidadãos todos os nativos, adultos e do sexo masculino que vivem em uma determinada sociedade. 
pensamento de Coluccio Salutati a manutenção de alguns elementos da Escolástica ${ }^{15}$, como por exemplo a relação entre a forma de governo e a preservação da paz. Tanto para os escolásticos quanto para Salutati, as dissensões sociais são a causa da eliminação da paz. Dessa forma, Salutati compreendia que para solucionar esse impasse seria necessário o estabelecimento do governo de um só, o qual eliminaria os conflitos sociais e garantiria a manutenção da paz.

Os pensadores do medievo estiveram atentos às problemáticas de seu tempo e propuseramse a enfrentar a realidade ao seu entorno por meio de uma reflexão histórica e teórica. Essas reflexões foram essenciais para a compreensão da sociedade medieval, a qual passava por importantes transformações que exigiam uma base ideológica para sustentar as mudanças que resultariam na formação da sociedade moderna. Diante do legado dessa intelectualidade, Nicolau Maquiavel promoveu uma ruptura com o pensamento tradicional à medida que esse considerava as dissensões sociais como um risco à manutenção da paz, enquanto Maquiavel compreendeu as dissensões sociais como fonte de promoção da liberdade.

\section{Nicolau Maquiavel: Os humores e a ação tumultuária}

Nicolau Maquiavel foi um defensor do regime republicano, pois compreendia que nas Repúblicas os indivíduos possuíam um vínculo forte com suas raízes, o que os levava a lutar com mais vigor contra ameaças externas e internas. Seu modelo de análise foi a República Romana que, segundo Maquiavel, atingiu a perfeição pois soube equilibrar as três formas de governo: a Monarquia representada pelos Cônsules, a Aristocracia constituída no Senado e o Estado Popular representado pelos Tribunos da Plebe. O pensador florentino ainda atribui à perfeição da República Romana o fato de permitir a ocorrência de conflitos sociais, o que possibilitou a fundação da liberdade romana, por meio da instituição dos Tribunos da Plebe. Segundo Nicolau Maquiavel,

Portanto, deve-se censurar o governo romano com mais comedimento; e considerar que tantos bons efeitos oriundos daquela república só podiam ser causados por ótimas razões. E se os tumultos foram razão para a criação dos tribunos, merecem sumos louvores; porque, além de concederem a parte que cabia ao povo na administração, tais tribunos foram constituídos para guardar a liberdade romana. (Maquiavel, 2000:23).

Com uma compreensão realista sobre a experiência histórica dos indivíduos ${ }^{16}$, Nicolau Maquiavel assumiu uma postura heterodoxa defendendo a discórdia civil como um importante elemento constitutivo de uma República virtuosa e negando a compreensão da sociedade numa perspectiva da concórdia.

\footnotetext{
${ }^{15}$ A Escolástica pode ser analisada por dois ângulos: o primeiro enquanto uma metodologia de aprendizagem praticada nas Universidades; e o segundo, como um movimento cultural de caráter político que possibilitou o surgimento de importantes teorias sociopolíticas, assim fornecendo elementos para a emergência do movimento humanista.

16 O realismo de Nicolau Maquiavel estava fundamentado na ideia da verità effettuale dela cosa (a verdade efetiva da coisa). Maquiavel desejava uma Itália unificada, por isso defendia a construção de um novo edifício social e político, no qual o homem real, o homem de seu tempo fosse o centro. Diante da negação do medievo em relação à vida terrena e à verdade da realidade, Nicolau Maquiavel propunha o restabelecimento da vida terrena, de sua consciência e das forças que nela operavam. Dessa forma, o homem não era passivo ou contemplativo; mas sim um ser que agia sobre o real, um ser ativo e atuante. Maquiavel apostava na transformação por meio da leitura da realidade efetiva e das relações de forças existentes.
} 
Não quero deixar de falar dos tumultos que houve em Roma desde a morte dos Tarquínios até a criação dos tribunos; depois, quero dizer algumas coisas contra a opinião de muitos, segundo a qual Roma foi uma república tumultuária [...]. Direi que quem condena os tumultos entre nobres e a plebe parece censurar as coisas que foram a causa primeira da liberdade de Roma e considerar mais as assuadas e a grita que de tais tumultos nasciam do que os bons efeitos que eles geravam; e não consideram que em toda República há dois humores diferentes, o do povo, e o dos grandes, e que todas as leis que se fazem em favor da liberdade nascem da desunião deles. (Maquiavel, 2000:21-22).

Nicolau Maquiavel defende a existência de uma oposição irredutível entre os humores dos grandes - que desejam dominar - e os humores do povo - que não querem ser dominados, conforme explicitado em sua obra O Principe:

Pois, em todas as cidades, existem esses dois humores diversos que nascem da seguinte razão: o povo não quer ser comandado nem oprimido pelos grandes, enquanto os grandes desejam comandar e oprimir o povo. (Maquiavel,2008:43).

No entanto, Nicolau Maquiavel apresenta duas dimensões do humor. Um humor natural e homogêneo, caracterizado pelo desejo natural do ser humano de levar vantagem sobre o próximo, visandoà obtenção de riquezas e honrarias - essa dimensão do desejo conduz os indivíduos a uma concorrência entre si. A outra dimensão, um humor político e heterogêneo que produz uma relação dissimétrica entre duas ordens de cidadãos: os grandes e o povo. No primeiro caso temos o conflito humano, no segundo o conflito político, o qual nos permite compreender as diferenças entre grandes e povo enquanto cidadãos.

No pensamento maquiaveliano há indicações sinalizando que para Maquiavel a força motriz do processo de estruturação das sociedades seja a "luta de classes". A centralidade do tema a luta entre dois humores conduziu à reformulação do conceito de popolo por Nicolau Maquiavel. Heller sublinha essa inovação assinalando:

O popolo florentino tradicional englobava, em princípio, todos os habitantes da cidade; mas, na prática, referia-se aos mais ilustres e capazes, aqueles que participavam na direção dos assuntos públicos. Em Maquiavel essa noção do povo foi invertida. O verdadeiro estrato dirigente (aquilo que até então tinha sido designado por 'povo') era agora incluído na categoria dos 'ilustres', em vez de ser na do povo, e dentro delas os nobres e os burgueses constituíam ainda dois grupos separados; o povo era agora o estrato social inferior, os pobres e desfavorecidos. (Heller,S/d:270).

Em sua análise dos Discursos, Heller (S/d) afirma que Nicolau Maquiavel, ao tratar das discórdias civis, amplia o conceito de povo e transforma o conceito de "luta de estratos sociais" em "luta de classes". Segundo a autora isso significa que: "[...] a base de estratificação social de Maquiavel é o sistema econômico da sociedade burguesa e não a estrutura política da pólis."(Heller, S/d: 270).

O historiador Claude Lefort (1986) assinala que a obra de Nicolau Maquiavel aponta uma base econômica para as discórdias civis: a reforma agrária. Lefort ainda salienta que ao estabelecer uma relação entre a formação de classes e a organização do poder com a luta pela conquista de bens Maquiavel inaugura conceitos da moderna economia. Analisando os Discursos, Lefort aponta:

Quem duvidasse do pensamento de nosso autor deveria considerar o que a seus olhos está fundamentalmente em jogo nos tumultos da República romana - estes famosos tumultos de 
onde nascem todas as boas leis: o que está em jogo é a reforma agrária[...]. É verdade que não descobrimos nos Discursos uma verdadeira análise do sistema de propriedade em Roma, das mudanças sobrevindas na repartição da terra[...]. Não podemos, porém, ignorar que sua obra traz em germe uma concepção moderna da economia, pois relaciona a formação das classes e do poder à luta pela apropriação dos bens. A opressão de que fala implica o que chamamos de exploração. Nenhuma referência - é verdade - a uma finalidade do corpo social, nenhuma imagem de uma hierarquia de funções fundada sobre a divisão do trabalho, nenhuma teoria das necessidades naturais ou sociais. Mas uma consciência aguda do conflito entre detentores da riqueza e "pés-de-chinelo". (Lefort, 1986:150-152).

No entanto, em sua obra História de Florença, Nicolau Maquiavel condena as discórdias civis tanto na Roma Antiga quanto em Florença, pois compreendia que tais inimizades trouxeram desunião, divisão e perturbação para a República. Porém, ressalta que em Roma as cisões promoveram resultados positivos, pois as inimizades foram resolvidas por meio do diálogo; ao contrário de Florença, onde as inimizades resultaram em combates.

As graves e naturais inimizades que existem entre as pessoas do povo e os nobres[...] são motivos de todos os males que surgem nas cidades, porque desta diversidade de humores nutremse todas as outras coisas que perturbam as repúblicas. Foi isso que manteve Roma desunida [...] e manteve Florença dividida; diversos foram os efeitos resultantes numa e noutra cidade, as inimizades que no início surgiram em Roma entre o povo e os nobres definiram-se discutindo, e em Florença, combatendo. (Maquiavel, 1998: 143).

Em História de Florença, Maquiavel narra a diversidade de cisões ocorridas em Florença desde 1353, quando do início das inimizades entre duas das principais famílias oligárquicas os Albizzi e os Ricci, até a morte de Ladislau I (1377-1414), rei de Nápoles. A análise de Nicolau Maquiavel sobre esse período de incessantes discórdias civis em Florença é de crítica e desagrado. Esta postura negativa em relação aos conflitos civis se justifica por algumas razões. Em primeiro lugar, as discórdias civis que ocorreram em Florença não foram movidas por interesses coletivos, mas sim por ambições e interesses privados ou facciosos. Em segundo, o poder político era utilizado para prejudicar os inimigos, seja expropriando-lhes os bens, expulsando-os de seus cargos públicos, exilando-os ou matando-os - o que fazia o ódio aumentar entre a população florentina. Por fim, a presença permanente do sentimento de inveja e desejo de vingança. Dessa forma, Maquiavel assinalou a negatividade dos tumultos em Florença, pois compreendia que suas motivações eram extremamente prejudiciais a qualquer ordenamento social e político. Além disso, os tumultos em Florença resultavam em combates armados entre os segmentos sociais que compunham a cidade, podendo levar ao esfacelamento das instituições políticas e da ordem social.

E como a cidade estava cheia de diversos humores, cada um diversos fins tinha, e todos, antes de pousá-los, desejavam atingi-los. Os antigos nobres, chamados Grandes, não podiam suportar ficar sem os cargos públicos, e por isto se engenhavam de qualquer maneira para recuperálos, e para isto desejavam que se desse autoridade aos Capitães de Partido; desagradava aos notáveis do povo e às Artes Maiores o fato de o estado ser acomunado às Artes Menores e o povo miúdo; por outro lado, as Artes Menores queriam aumentar ao invés de diminuir sua dignidade; e o povo miúdo temia perder seus cargos nos Colégios de suas Artes. Estas discrepâncias ocasionaram muitos tumultos, durante um ano, em Florença; ora tomavam armas os Grandes, ora as Artes Maiores ou Menores e, com estas, o povo miúdo; e muitas vezes de repente diversos pontos do território estavam em armas. (Maquiavel, 1998:172).

No entanto, na obra Discursos, Nicolau Maquiavel compreende que as divergências entre a 
plebe e o Senado tornaram Roma uma República livre e poderosa, pois essas divergências não resultavam em violência entre os cidadãos nem em tentativas de facções ou indivíduos para assumirem o poder.

Se alguém, portanto, quiser ordenar uma nova república, terá de examinar se quer que ela cresça em domínio e poder, como Roma, ou que permaneça dentro de limites exíguos. No primeiro caso, é necessário ordená-la como Roma e dar lugar da melhor maneira possível a tumultos e a dissensões entre cidadãos. (Maquiavel, 2000:30).

Por conseguinte, devemos esclarecer o uso que Nicolau Maquiavel faz dos termos discórdias civis e tumultos. Na obra História de Florença, o autor lamenta as dissensões sociais entre nobres e povo; nos Discursos, os tumultos são amplamente elogiados. Grazia sinaliza para o significado do termo tumulto nos Discursos:

As divisões civis e inimizades naturais lamentadas por Niccolò não devem ser confundidas com os tumultos elogiados nos Discursos. Os tumultos, palavra aqui escolhida por ele, consistem em conflitos internos que "raras vezes geravam exílios, e raríssimamente sangue". Ao que parece, ele refere a movimentos de protestos civis: "O povo junto a gritar contra o Senado, o Senado contra o povo, a correr tumultuadamente pelas ruas, a fechar as lojas, toda a plebe de Roma a ir embora, coisas estas que só assustam a quem as lê". "Tais formas de protesto não geram qualquer exílio ou violência em prejuízo do bem-comum, e sim leis e ordens em benefício da liberdade pública" - desde que a pátria já não esteja corrompida e seus homens tenham em vista "o bom fim". Então os tumultos não prejudicam; "pelo contrário, auxiliarão a república”. Dão uma sintonia mais fina às leis. (Grazia, 1995:195-196).

Nicolau Maquiavel compreende a existência dos humores como um elemento natural, pois, para o pensador florentino está presente nas "coisas humanas". Os humores consistem nas inimizades entre povo e nobres; sendo a causa dessas inimizades o fato desses quererem mandar e aqueles não quererem obedecer. Maquiavel analisou a questão dos humores à luz da experiência histórica romana para compreender e explicar os fatos ocorridos em Florença. Defendeu as discórdias civis frente ao pensamento tradicional, o qual compreendia as discórdias como a causa da perturbação da paz. Do ponto de vista do pensamento maquiaveliano, os tumultos da Roma Antiga eram expressão da participação política, ou seja, expressavam a virtù cívica. Os tumultos em Roma possibilitaram a formação dos Tribunos da Plebe os quais eram os responsáveis pela representatividade do povo na administração e pela guarda da liberdade romana. Segundo Maquiavel,

Portanto, deve-se censurar o governo romano com mais comedimento; e considerar que tantos bons efeitos oriundos daquela república só podiam ser causados por ótimas razões. E se os tumultos foram razão para a criação dos tribunos, merecem sumos louvores, porque, além de concederem a parte que cabia ao povo na administração, tais tribunos foram constituídos para guardar a liberdade romana. (Maquiavel, 2000:23).

Nicolau Maquiavel compreende que a liberdade é o fim último das sociedades, pois sem ela o que resta é a servidão, corrupção e degeneração. A liberdade foi um bem caro a Maquiavel, pois sua tese sobre a conquista e manutenção da liberdade rompeu com toda uma tradição do pensamento político, uma vez que o pensador florentino defendeu a existência de dois humores - os grandes e o povo: o primeiro querendo dominar e o segundo não querendo ser dominado - os quais desencadeavam as dissensões sociais, as quais resultam na elaboração de novas leis e novas ordenações, promovendo a liberdade. A liberdade tem seu conceito ampliado, pois também 
incorpora a ideia de participação nos negócios públicos da cidade pela população e como consequência o desenvolvimento de uma cidade mais igualitária. $O$ pensador florentino conclui que a guarda da liberdade deve ser concedida ao povo, pois o povo teme perdê-la e por isso lutará pela sua manutenção, mas não para tê-la somente para si.

$\mathrm{E}$, indo às razões, direi, vendo primeiro o lado dos romanos, que se deve dar a guarda de uma coisa àqueles que têm menos desejo de usurpá-la. E sem dúvida, se considerarmos o objetivo dos nobres e o dos plebeus, veremos naqueles grande desejo de dominar e nestes somente o desejo de não ser dominados e, por conseguinte, maior vontade de viver livres, visto que podem ter menos esperança de usurpar a liberdade do que os grandes; de tal modo que, sendo os populares encarregados da guarda de uma liberdade, é razoável que tenham mais zelo e que, não podendo eles mesmos apoderar-se dela, não permitirão que outros se apoderem. (Maquiavel,2000:24).

\section{Algumas considerações sobre a contemporaneidade de Nicolau Maquiavel}

O propósito de trazer uma discussão sobre o pensamento de Nicolau Maquiavel para pensarmos o ensino de História no século XIX é justificado pelo fato de compreendermos que Nicolau Maquiavel é um pensador que pode nos oferecer importantes questões para refletirmos sobre nossa atualidade. Primeiramente, Nicolau Maquiavel foi um dos principais representantes do pensamento político italiano que se dedicou a pensar sua época e traçar caminhos possíveis e eficazes para a condução da política italiana e, em especial, de Florença. Em suas análises, Maquiavel dialogou com o passado em busca de compreensão dos problemas do presente. Porém, para o pensador florentino a retomada do passado não significava uma mera imitação; mas sim, a verificação da existência ou não - no presente - de elementos que orientaram os Estados antigos e, assim, aferir se os problemas do presente eram passíveis de soluções com o uso de regras da Antiguidade. Dessa forma, Nicolau Maquiavel assinalou a necessidade do confronto entre circunstâncias do passado e do presente; assim como demonstrou que em quaisquer sociedades a disputa pelo poder é marcada por leis universais, às quais servem a quem quer que decida disputar o poder.

Em segundo, Nicolau Maquiavel confrontou a tradição intelectual ao defender a necessidade das discórdias civis, pois concebeu a liberdade como fruto da oposição entre grupos distintos, como uma liberdade política que é o direito de opor-se pacificamente a quem está no poder. O pensador florentino demonstrou que as leis garantem aos homens as condições para manterem sua individualidade e atuarem no cenário político com igualdade e liberdade, assinalando que a liberdade deriva das leis, a qual decorre das dissensões sociais. No entanto, Nicolau Maquiavel atenta para a importância de boas leis, pois devem preservar a liberdade à medida que orientam as ações no sentido do interesse comum dos grupos em conflito e, dessa forma, promovem o desenvolvimento da virtù nos cidadãos. Nesse sentido, Maquiavel ressalta que a força de um Estado depende da participação popular, a qual só ocorre quando há liberdade de manifestação. Seu argumento é que todo Estado tem tendência à corrupção, ao declínio e à servidão; mas onde há liberdade essa degeneração do Estado pode ser retardada e a grandeza cívica ser longínqua.

Por fim, Nicolau Maquiavel atentou para o fato de que a grandiosidade dos Estados depende da manutenção dos interesses coletivos, e são nas Repúblicas que encontramos os instrumentos institucionais capazes de canalizar os interesses opostos - os dois humores - os quais estariam presentes em toda comunidade política. O pensador florentino salientou ainda que somente a forma republicana de governo é capaz de garantir a liberdade. Maquiavel compreende que 
somente numa República a liberdade pode ser assegurada, pois a forma de governo republicano possibilita a existência de instituições legitimadas para a participação do cidadão na política.

Atualmente, experimentamos uma queda na participação política que atinge a democracia no Brasil, o que nos força a refletir acerca dos desafios colocados à nossa República. Nesse cenário, revisitar autores como Nicolau Maquiavel que compreende a República como um esteio para a participação política de cidadãos e a conquista e manutenção da liberdade, pode auxiliar no enfrentamento de importantes obstáculos à consolidação de nossa democracia. Nos dias atuais, como na época de Nicolau Maquiavel, não devemos renunciar à política como um importante instrumento para a resolução dos problemas sociais. O pensador florentino evidenciou que o caminho a ser seguido para alcançar uma sociedade mais igualitária deve ser a participação política por parte da sociedade civil. Participação política que possibilite o envolvimento da sociedade civil em movimentos sociais que engendrem políticas públicas em benefício da coletividade. Além disso, Nicolau Maquiavel defende a virtù como característica nevrálgica da liderança política para empreender uma ação política. Um líder político deve ser aquele que tenha capacidade para unificar as forças sociais em torno de si. Um líder político deve ter aptidão para liderar e manter a estabilidade do poder, combinar coragem e capacidade de representação dos interesses da sociedade como um todo, entre os quais o imprescindível é o da liberdade.

\section{Referências Bibliográficas}

ALIGHIERI, Dante. De La Monarquia. Buenos Aires: Editorial Losada, 1941.

AMES, José Luiz. Maquiavel: A lógica da ação política. Cascavel: EDUNIOESTE, 2002.

BARON, Hans. En busca del Humanismo cívico Florentino - ensayos sobre el cambio del pensamiento Medieval al Moderno. México: Fondo de Cultura Económica, 1993.

BERLIN, Isaiah. Quatro Ensaios sobre a Liberdade. Brasília: Editora Universidade de Brasília, 1981. BIGNOTO, Newton. Maquiavel Republicano. São Paulo: Edições Loyola, 1991. (Coleção filosófica; V.19).

BRUDNEY, Kent M. (Nov./1984). Machiavelli on Social Class and Class Conflict. Political Theory, Vol. 12, No. 4. p. 507-519.

DRESDEN, Sem. O Humanismo no Renascimento. Porto: Editorial Nova Limitada, 1968.

DUVERNOY, Jean J. F. Para conhecer o pensamento de Maquiavel. Porto Alegre: L \& PM Editores, 1984.

ESCOREL, Lauro. Introdução ao pensamento político de Maquiavel. Rio de Janeiro: Organização Simões Editora, 1958.

ESPOSITO, Roberto. La política e La storia - Machiavelli e Vico. Nápoles: Liguori Editore. 1980.

GILBERT, Felix.(Dez./1939)The Humanist Concept of the Prince and the Prince of Machiavelli. The Journal of Modern History. Vol.11, n. 4. p. 449 a 483.

GRAZIA, Sebastian de. Maquiavel no Inferno. São Paulo: Companhia das Letras, 1995.

GUERRERO, Rafael Ramón. Historia de La Filosofia Medieval. Madrid: EdicionesAkal, 2002.

HELLER, Agnes. O Homem do Renascimento. Lisboa: Editorial Presença. S/d.

LARIVAILLE, Paul. A Itália no tempo de Maquiavel: Florença e Roma. São Paulo: Editora Companhia 
das Letras, 1988.

LEFORT, Claude. Le Travail Machiavel. Saint Amand: Éditions Gallimard, 1986.

LE GOFF, Jacques. A Civilização do Ocidente Medieval. Bauru, SP: Editora da Universidade do Sagrado Coração, 2005.

MAQUIAVEL, Nicolau. Comentários sobre a primeira década de Tito Lívio "Discorsi". Brasília: Editora Universidade de Brasília, 2000.

. História de Florença. São Paulo: Musa Editora, 1998.

. O Príncipe. São Paulo: Martins Fontes, 2008.

PÁDUA, Marsílio de. O defensor da Paz. Petrópolis: Editora Vozes, 1997.

PEREIRA, Joacil de Brito. Idealismo e Realismo na obra de Maquiavel. Brasília: Horizonte Editora. 1981.

RIDOLFI, Roberto. Biografia de Nicolau Maquiavel. São Paulo: Musa Editora, 2003.

SKINNER, Quentin. As fundações do pensamento político moderno. São Paulo: Companhia das Letras, 1996.

. Maquiavelo. Madrid: Alianza Editorial. 1984.

TENENTI, Alberti. Florença na época dos Médici: da Cidade ao Estado. São Paulo: Editora Perspectiva. 1973.

Artigo recebido em: 16/04/2019

Artigo aceito em: 28/05/2019 